\title{
Global Population Stabilization Policy and Declining Work-Age Population: A Threat to Global Economic Sustainability
}

\author{
Md. Mahmudul Alam* \\ School of Economics, Finance \& Banking \\ Universiti Utara Malaysia \\ Kedah, Malaysia \\ Email: rony000@gmail.com \\ Md. Wahid Murad \\ UniSA College \\ University of South Australia \\ Adelaide, Australia \\ E-mail: wahid.murad@unisa.edu.au \\ Rafiqul Islam Molla \\ International Islamic University Chittagong \\ Chittagong, Bangladesh \\ E-mail: rimolla@gmail.com \\ Khondaker Mizanur Rahman \\ Graduate School of Business Administration, and \\ Faculty of Policy Studies \\ Nanzan University \\ 489-0863 Seto-shi, Japan \\ E-mail: kmrahman@ps.nanzan-u.ac.jp \\ Taslima Rahman Khondaker \\ English Language Center \\ Nanzan University \\ Nagoya, Japan \\ E-mail: taslimarkhondaker@gmail.com \\ * Corresponding author

\section{Citation Reference:}

Alam, M.M., Murad, M.W., Molla, R.I., Rahman, K.M. \& Khondaker, T.R. (2019). Global Population Stabilization Policy and Declining Work-Age Population: A Threat to Global Economic Sustainability. International Journal of Environment and Sustainable Development, 18(4), 369-386. (online) http://dx.doi.org/10.1504/IJESD.2019.103469

This is a pre-publication copy.

The published article is copyrighted by the publisher of the journal. 


\title{
GLOBAL POPULATION STABILIZATION POLICY AND DECLINING WORK- AGE POPULATION: A THREAT TO GLOBAL ECONOMIC SUSTAINABILITY
}

\begin{abstract}
Faced with an exponentially growing world population, what is required is a population stabilization policy to control the global fertility rates. This has implications for the workingage population in the future, and lead to a serious economic crisis. It is envisaged that by the year 2050 the work-age population will have seriously declined but is still expected to look after an increasing dependent population. This paper argues that to maintain sustainable economic growth, and to support the associated technological advances in the future there will be demand for a larger labor force. It notes that the industrialized countries are now managing with migrant populations drawn mostly from high fertility but low-income countries. In the global context this is only a zero-sum game without increasing the stock of the world's actual total labor force. Therefore, the world population needs to increase to meet the growing demand for a larger labor force in order to achieve economic sustainability. Since the earth's population carrying capacity largely depends on advanced technology functioning well, to support society's lifestyle expectations, the world should not defer planned population growth.
\end{abstract}

JEL codes: J11, J22, O15

Key words: population growth; fertility rate; work-age population; dependency ratio; economic sustainability; zero-sum game; 'child bearing habitual gap'; 'work-age formation gap'; 'slim-green' life style.

\section{INTRODUCTION}

The world's population explosion throughout the last century from 2.55 billion in 1950, to 7.7 billion in 2019. It is projected to reach 10 billion in 2055, and 11.2 billion in 2100 (Worldometers 2019). The hidden momentum of population growth, has a built-in tendency to continue growing even after birthrates have declined substantially or declined to a replacement rate, i.e. parents have only two children to replace themselves (Todaro and Smith 2009). Accordingly, it is estimated that if the population continues to grow at the 1990s rates, the world population will reach 694 billion by 2150 ; if it grows at a rate just one-tenth above the replacement rate it will reach 12.5 billion by 2050 and 20.8 billion by 2150 . Furthermore, if it grows at only the replacement rate it will reach 7.7 billion by 2050 , and 8.4 billion by 2150 (Cohen 1995a). These are obviously very large population numbers. However, these figures have to be considered in conjunction within the limits of the earth's population carrying capacity.

\section{Earth's Population Carrying Capacity Debates}

Between 1679 and 1994 there were 65 estimates undertaken on the earth's populationcarrying capacity. These estimates vary widely ranging from fewer than a billion to more than a trillion (Cohen 1995b). These estimations took sustainability into account as a necessary and significant condition so that the needs and aspirations of the present population can be met without compromising the ability of the future generations to meet their own needs (Brundtland 1987, p. 43). Based on the agricultural systems in place the population carrying capacity was estimated to be some 902 million in 1945, and as high as 147 billion in 
1967. In 1965, Walter Schmitt estimated the earth's population carrying capacity to be 30 billion (Cohen 1992); Ehrlich (1968) estimated even 3.5 billion as being above the earth's capacity; Pimentel et al. (1994) estimated 2 billion as the earth's maximum carrying capacity; and the Worldwatch Institute (1998) estimated it to be 11 billion.

Nonetheless, almost all the scholars seem to agree that the earth's human carrying capacity finally depends on advances made in technology (ability to unlock/create useful resources from the earth's environment) and people's economic choices (lifestyle, social structure, etc.). Its biophysical carrying capacity sets the maximum population size that could be sustained biophysically under the given technological capabilities and its social carrying capacity. It is worth noting that human ingenuity, through centuries of innovations and adaptations of social and industrial engineering and technology, has made possible dramatic increases in both the biophysical and the planet's social population-carrying capacity. Although human ingenuity is capable of overcoming natural barriers, there are theories which deny the existence of any finite carrying capacity at all. Alternatively, there are theories which acknowledge that the limits of the earth's capacity are real, and recognize that human choice, now and in the future, will largely determine where those limits fall. The truth of the matter is that there is no single numerical answer, now or ever, to the question how many people the earth can carry; it can at best be conditional (Weil 2009, p.139). However, the bottom line is that the laws of thermodynamics inevitably limit the biophysical carrying capacity (Fremlin 1964, Paul \& John 2011).

\section{Earth's Population Feeding Capacity Debates}

Dynamic and ongoing debates exist among nations, international bodies, and scholars regarding the earth's capacity to feed its rising human population (Singh 2009, Godfray et al. 2010, Population Action International 2011, Prasad 2013, Hunter 2016, Elferink \& Schierhorn 2017, Hall et al. 2017, Hasell 2018, Hincks 2018, Population Connection 2019). Some are very fearful of the imminent danger of food shortages for the rapidly increasing world population. They believe this fear to be real. Others suggest there is nothing to fear because the earth has tremendous and endless potential for increased volumes of food production for feeding larger populations in the future.

The International Society of Soil Science (ISSS) in 1927 suggested that the earth would be able to feed at most approximately 16 billion people (Penck 1928). However, a more rigorous quantitative study that set out to estimate world food production was first conducted in the mid-970s. It was assumed that less than half of the world's potential agricultural land was actually cultivated (Buringh et al. 1975). Taking into account the regional aspects of food production and productivity, an assessment was made of land resources and productivity of more than 200 regions of the world. Production was expressed in grain equivalence of a standard cereal crop. Accordingly, it is estimated that the world had the capacity to produce 40 times the level of food production in 1975. At present, the world produces more than enough food required to feed the entire global population. Unfortunately, a large number of people in many parts of the world are in fact starving and suffering from undernourishment (Latham 2000). Reportedly, in absolute terms, the world may be already producing enough food to feed as many as 10 billion people, yet in reality the bulk of this feed. It is given animals in order to increase the production of meat, dairy, and poultry products mostly in the world's richer countries. The argument here is that the poverty and not physical shortage of food is considered to be the primary cause of hunger in the world (Buringh 1982; Latham 2000; Pinstrup-Andersen 1998). 
However, the FAO in 1999 estimated 800 million people or $18 \%$ of the world's population suffered from undernourishment in poorer countries, but for the late 1960s the estimate was 960 million or $37 \%$ of the population (FAO 2003). Nowadays current projections indicate that the number of undernourished people will decrease to about 576 million by 2015, and approximately 401 million by 2030 . This projected decline in the number of undernourished people in the world signals improvement of the situation in the future. It is estimated that the earth has the capacity to produce enough food to feed even a few billion more than the population in 2020 if all its resources are harnessed and efficiently managed (Greenland et al. 1997). However, much will depend on political will and resolutions made by the world community. Another recent estimate showed that a 2- to 4-fold increase in food production can be easily achieved to satisfy the growing population (Penning de Vries et al. 1997). This estimate is based on the potential production limited by atmospheric variables and the availability of all surface water for irrigation.

Moreover, evidence suggests that negative effects of population growth on food supply are usually relatively small. Sen (1994) conclusively showed that famine and destitution have rarely been caused by population growth or size. He argues that there is no serious evidence to suggest that the rate of population growth is outrunning the earth's ability to produce enough food to feed everyone. Similarly, we find that between 1960 and 2000 the world population doubled. However, the 'green revolution' led to better varieties of crops, improved irrigation and drainage, increased fertilizers for improved pest and weed control, and affordable supervised credit, advances in food storage and transport, and increased areas for agriculture, etc. (Ross 1999). Todaro (2009) also supports the contention that population growth is not the primary cause of underdevelopment and low levels of living in the developing world.

Nevertheless, as mentioned earlier, due to the inequitable distribution of food production many people starve or remain undernourished even when in absolute terms the world's total food production is more than enough to feed the whole population. Therefore, for the world as a whole to have the ability to generate enough food for its population alone is not enough for avoiding starvation and undernourishment in many regions. In fact, it is necessary to produce more food where it is needed (Dudal 1982). This is the most serious problem under the present global political and other institutional structures. Under these circumstances it is argued that the fear of hunger and starvation is very real for a large proportion of the world's population. There is the danger that a constantly increasing population will have serious implications for the world's food security.

\section{Fear of Population Crash and Call for Stabilization}

Beyond the debate on the earth's population carrying and feeding capacity, it is argued that caution is required in controlling population growth so that a population crash does not occur (Ehrlich \& Ehrlich 1990, Desvaux 2007, Team 2009, Emmott 2013, Dimick 2014, Emmott 2015, Moody 2017). These alarmists in the 1950s reported on the danger of future population explosions. Consequently, in response to that warning the United Nations and the agencies under its umbrella, including those with links to national governments, international developmental bodies, non-government organizations (NGOs), and researchers, strongly emphasized the need to stabilize the world's population. 
Most countries took measures to arrest population growth. Unfortunately, there a significant negative effect of this policy on the world economy is evident. Through this policy is now envisaged that the annual growth rate of the world's population will decline from $1.3 \%$ in 2000 to $0.56 \%$ in 2050 , causing significant problems for the world economy. It is feared that from 2050 onward the world will have to deal with the great challenge posed by the declining number of work-age people. It is expected that the work-age dependency ratio, i.e. the proportion of youth (under 15) and old people (over 65) to economically active adults (1565), will increase. This will make it more difficult for a declining economically active population to support an increasing dependent population who cannot work. The decline of the work-age population will then generate low gross domestic product (GDP), low gross national income (GNI), and governments will not have sufficient tax revenues.

\section{OBJECTIVE AND METHODOLOGY}

This paper primarily aims to examine the adverse effects of the world's declining work-age population on the future world economy and suggests that technological innovations and necessary social engineering as a means of maintaining economic sustainability in the future. This paper is an outcome of research using secondary data obtained from various published national and international documents and journals. A content analysis of the literature is undertaken for this topic. It uses descriptive analyses using tables and simple statistical tools like averages, percentages, ratios, etc., to make the case that is argued here.

\section{RESULTS AND DISCUSSION}

\section{Fertility Rate and Population Structure}

One of the most serious effects of this population growth stabilization policy has been the continuous decline of the fertility rate (Myrskyla, Kohler \& Billari 2009, Population Fact 2017) and change in the population structure (Table 1). By 2043 the actual fertility level is projected to fall below the replacement fertility level ${ }^{1}$. The U.S. Census Bureau (2004) projected that the number of women in child-bearing years would decline gradually from about $52.1 \%$ of total female population in 2010 to $45 \%$ by 2050 (Table 2). In the last few decades in many developing countries the population under 15 years of age has grown rapidly, but now is now starting to decline. As a result, the world youth population aged 0-14 is projected to decline from approximately $26.5 \%$ in 2010 to about $20 \%$ by 2050 (Table 3). It is even more alarming that during the coming decades the world's elderly population will increase very rapidly as can be seen in Table 1. Consequently, the outcome of this critical decline in the youth population, is that the ratio of the global labor force (age 15-64) to total population is expected to rise only slightly from almost $56.5 \%$ in 2002 to near $58.5 \%$ in 2050 . It is then estimated there will be a sustained gradual decline threatening sustainability of the world economy in the coming decades (Table 4).

Table 1: World Average Fertility Rate per Woman

\begin{tabular}{|c|c|c|c|c|c|}
\hline Year & $\begin{array}{c}\text { Fertility Rate Per } \\
\text { Woman }\end{array}$ & Year & $\begin{array}{c}\text { Fertility Rate Per } \\
\text { Woman }\end{array}$ & Year & $\begin{array}{c}\text { Fertility Rate } \\
\text { Per Woman }\end{array}$ \\
\hline 1997 & 2.84 & 2015 & 2.46 & 2033 & 2.23
\end{tabular}

\footnotetext{
${ }^{1}$ The replacement level of fertility: the level of fertility at which each successive generation of women produces exactly enough offspring so that the same number of women survive to have children themselves.
} 


\begin{tabular}{|l|c|c|c|c|c|}
1998 & 2.8 & 2016 & 2.44 & 2034 & 2.22 \\
1999 & 2.76 & 2017 & 2.43 & 2035 & 2.21 \\
2000 & 2.74 & 2018 & 2.41 & 2036 & 2.2 \\
2001 & 2.7 & 2019 & 2.4 & 2037 & 2.2 \\
2002 & 2.67 & 2020 & 2.38 & 2038 & 2.19 \\
2003 & 2.66 & 2021 & 2.37 & 2039 & 2.18 \\
2004 & 2.64 & 2022 & 2.35 & 2040 & 2.18 \\
2005 & 2.63 & 2023 & 2.34 & 2041 & 2.17 \\
2006 & 2.61 & 2024 & 2.33 & 2042 & 2.17 \\
2007 & 2.59 & 2025 & 2.31 & 2043 & 2.16 \\
2008 & 2.58 & 2026 & 2.3 & 2044 & 2.16 \\
2009 & 2.56 & 2027 & 2.29 & 2045 & 2.15 \\
2010 & 2.54 & 2028 & 2.28 & 2046 & 2.15 \\
2011 & 2.53 & 2029 & 2.27 & 2047 & 2.14 \\
2012 & 2.51 & 2030 & 2.26 & 2048 & 2.14 \\
2013 & 2.49 & 2031 & 2.25 & 2049 & 2.13 \\
2014 & 2.48 & 2032 & 2.24 & 2050 & 2.13 \\
\hline
\end{tabular}

Source: U.S. Census Bureau 2000

Table 2: Global Women of Child-Bearing Age

\begin{tabular}{|l|l|l|l|l|l|l|}
\hline Year & $\mathbf{2 0 0 2}$ & $\mathbf{2 0 1 0}$ & $\mathbf{2 0 2 0}$ & $\mathbf{2 0 3 0}$ & $\mathbf{2 0 4 0}$ & $\mathbf{2 0 5 0}$ \\
\hline $\begin{array}{l}\text { \% of Total Female } \\
\text { Population }\end{array}$ & $52.1 \%$ & $52.1 \%$ & $49.8 \%$ & $48.2 \%$ & $46.4 \%$ & $45.0 \%$ \\
\hline
\end{tabular}

Source: U.S. Census Bureau 2004

Table 3: Age Group-wise Projected Population as Percentage of Total Population

\begin{tabular}{|l|l|l|l|l|}
\hline Year & $\begin{array}{c}\text { Youth } \\
\text { Population } \\
\text { (age 0-14) }\end{array}$ & $\begin{array}{c}\text { Young } \\
\text { Population } \\
\text { (age 15-29) }\end{array}$ & $\begin{array}{c}\text { Middle-age } \\
\text { Population } \\
\text { (age 30-64) }\end{array}$ & $\begin{array}{c}\text { Old-age } \\
\text { Population } \\
\text { (age 65 \& } \\
\text { over) }\end{array}$ \\
\hline 2002 & $29.0 \%$ & $26.0 \%$ & $37.9 \%$ & $7.1 \%$ \\
\hline 2010 & $26.5 \%$ & $25.5 \%$ & $40.3 \%$ & $7.7 \%$ \\
\hline 2020 & $24.8 \%$ & $23.3 \%$ & $42.4 \%$ & $9.5 \%$ \\
\hline 2030 & $22.9 \%$ & $22.1 \%$ & $43.0 \%$ & $12.0 \%$ \\
\hline 2040 & $21.4 \%$ & $21.4 \%$ & $42.6 \%$ & $14.6 \%$ \\
\hline 2050 & $20.4 \%$ & $20.2 \%$ & $42.9 \%$ & $16.5 \%$ \\
\hline
\end{tabular}

Source: U.S. Census Bureau 2004

Table 4: Projection of Economically Active Population as Percentage of Total and Dependency Ratio

\begin{tabular}{|c|c|c|c|}
\hline Year & $\begin{array}{c}\text { Economically } \\
\text { Active Population } \\
\text { (age 15-64) }^{\text {a }}\end{array}$ & $\begin{array}{c}\text { Economically } \\
\text { Inactive Population } \\
\text { (age 0-14 and 64 \& }^{\text {over) }}{ }^{\text {b }}\end{array}$ & $\begin{array}{c}\text { Dependency } \\
\text { Ratio }^{(b / a)}\end{array}$ \\
\hline
\end{tabular}




\begin{tabular}{|l|l|l|l|}
\hline 2002 & $63.9 \%$ & $36.1 \%$ & $56.5 \%$ \\
\hline 2010 & $65.8 \%$ & $34.2 \%$ & $52.0 \%$ \\
\hline 2020 & $65.7 \%$ & $34.3 \%$ & $52.2 \%$ \\
\hline 2030 & $65.1 \%$ & $34.9 \%$ & $53.6 \%$ \\
\hline 2040 & $64.0 \%$ & $36.0 \%$ & $56.3 \%$ \\
\hline 2050 & $63.1 \%$ & $36.9 \%$ & $58.5 \%$ \\
\hline
\end{tabular}

Source: US Census Bureau 2004

Spidla (2005) observed that the population decline is now a reality in more than a fifth of Europe. By 2050, the population in the European Union will decrease by almost 7 million and its work-age population will decrease by 55 million. By 2030, the work-age populations will most likely decrease by 21 million and youth numbers will plummet by 20 million. Conversely, the number of people over 65 years of age will increase by more than 39 million, and the number of persons over 80 years of age will virtually double. It is evident that the elderly population will increase rapidly, almost doubling by 2020, and more alarmingly tripling by 2050 . The elderly population will account for $9 \%$, and $17 \%$ of the total population by 2020, and 2050, respectively (U.S. Census Bureau 2004).

\section{Population Growth Dynamics}

Demographic history reveals that it takes many years or decades to change the direction of population growth trends. At present many developed countries like Switzerland, France, Japan, Germany, etc., which have negative population growth rates, are trying to change their people's child-bearing habits but without success. Many of these countries are already facing the problem of declining work-age population. Worldwide the life expectancy rates are increasing - and the death rate is decreasing, meaning there will be many more elderly people. Under these circumstances, stabilization of growth rates will require a decrease in the birth rate. Therefore, the countries trying to maintain a stable population, or zero growth rate have to reduce their birthrates, which in turn will cause a decrease in the work-age population. These countries are therefore faced with the problem of having birthrates as a double-edged sword - trying to stabilize population through birthrate reduction, and simultaneously trying to retain a sufficient work-age population.

The way out of this trap is to abandon the population stabilization strategy and plan for a population growth rate by increasing the child birthrate. The outcomes of this will only be realized after a long period of time has elapsed. This is because, firstly, any changes in people's child-bearing habits in favor of more children will take a long time - referred to as 'Child Bearing Habitual Gap' - to occur. Secondly, this change in family planning reproduction habits will be followed by a gap lasting another 15 years before these children are of working age. One study has referred to this as the 'Work-age Formation Gap' (Alam, et al., 2009). Moreover, the spread of deadly diseases and illness, among other factors, is significant in terms of population numbers adequate to grow the labor force in many parts of the world. The World Health Organization (WHO) estimated that there were approximately 36.9 million people worldwide living with HIV/AIDS in 2017. Nearly twenty years ago in 2002, WHO estimated that each year there are approximately 300-500 million cases of malaria, that lead to 1.1 million deaths. The World Bank (2004) estimated that tuberculosis alone kills nearly 2 million each year, and these victims were mainly 15-45 years of age. Consequently, the population growth in the coming years and decades for the high fertility 
rate regions will not be adequate to supply the required labor force even for their own regions and country.

\section{Declining Work-Age Population Threatens Economic Growth and Advances in Technology}

The population growth stabilization strategy (zero growth) directly impacts the future world economy. For example, when population growth rate is negative or zero, countries will have less of a work-age population and more older workers. Government's main source of income (tax revenue) chiefly originates workers' incomes. For that reason, the declining work-age population will mean a reduction in governmental tax revenues. The World Economic Outlook (2004) reports that between 1960 and 2000 per capita growth (GDP) is positively related to the increase in the size of the working age population, and negatively related to the increase in the size of the elderly population. Therefore, an increase in the life expectancy old age people throughout the world is now occurring. This is simply adding to the further expenses required for old-age transfer payments, for example pensions. It is feared that during the coming decades of this century most countries, especially the developed ones, will face the problem of having tax revenues too low to meet the high government expenditure on larger numbers of old-age people.

This will cause governments to maintain deficit budgets for the foreseeable future. In fact, Australia, Japan, Germany, Switzerland and others are already threatened by this major problem. Japan, for example, had a population of 123.5 million in 1990, and the rate of reproduction has slowed down so that it had 127.8 million in 2005. It was forecast for Japan that its population would decline to 124 million in 2015, then 115 million in 2030 (JILPT 2007b). The total national labor force was 63.9 million in 1990, and 66.6 million in 2005; and it is projected to decline to 58.3 million at the end of 2030 (JILPT 2007a). In fact, Japan already has a graying society wherein approximately $20 \%$ of its population is now over the 65 years of age group. It is suggested this will increase to about $30 \%$ by 2020 . Thus, Japan will face the challenge of replenishing its labor force to maintain sustainable levels of its GDP and GNI.

However, the future decline in the labor force in turn will increase the costs of production, and therefore inflation rates will become extreme. An economic crisis is likely to occur the world over especially from 2050 onwards. This decline in the work-age population will directly impact on technological advances and developments, which is essential for continuous growth in GDP. Technological advances mean not only updating how existing industries currently operate but also extending new technologies to new sectors. Overuse of technology in one sector creates over-capitalization and leads to only marginal economic gains. Essentially, this means that updating technological innovations in the same sector will be less profitable than creating new technology in new sectors. This will create demand for additional human resources and capital.

In the OECD countries, there has been a steady increase in the labor force engaged in research and development (R\&D) between 1981 and 2005 (OECD Factbook 2009). At this time it increased from 4.6 persons to 7.3 persons per thousand. In terms of percentages of the total workforce, this represented an increase from $0.5 \%$ to $0.7 \%$. The current state of technology in the G-5 countries means that the number of researchers in these nations grew 10 -fold from 0.25 million in 1950 , to 2.6 million in 2005 . To maintain the current level of technological growth by engaging the same quality of highly skilled researchers, this will 
require 26 million and 260 million researchers in 2060 and 2115, respectively (Weil 2009, p. 260). If these nations fail to employ the required number of researchers who are creating new technologies, the scenario be one of stagnation in technological growth.

Furthermore, many parts of the world have not yet experienced industrialization. When the industrialization processes begin in these countries, a huge labor force will be required. After reaching the maturity stage of industrialization, these countries will rapidly develop into more service-orientated industries. In most cases the service sectors are still labor intensive. Therefore, in the coming decades there will be a need for a larger labor force worldwide, and various governments will be required to embark upon a sound human resources and assets planning. It will also be necessary to make sure that such plans are compatible with population growth rate policy.

\section{POLICY SUGGESTIONS}

Short-term measures, for instance, importing labor from labor surplus areas could perhaps be tried as a temporary solution to this problem. However, this should not ignore any long-term solutions that must be addressed through effective population growth strategies to achieve growth in the work-age population. This necessitates a revision of the population stabilization policy in favor of just the planning of population growth. The following policy suggestions are expected to help the concerned nations maintain economic sustainability for the future.

\section{Temporary Measure: Immigration}

In order to cope with labor shortages, industrialized countries are now engaging in a mix of short-term or temporary and permanent migration of human resources mainly from high fertility but low-income developing countries. This is done in various ways, for example, the granting of citizenship, permanent residence status (PR certificate, green card, diversity visaDV, etc.), work permits to foreigners, accepting asylum-seekers and refugees, admitting international students and permitting them to stay on to work after completion of studies, etc. Under the DV scheme alone the United States receives approximately 50,000 permanent immigrants from these developing countries. During 2005-2007 more than 1.1 million foreigners per year were granted permanent resident status in the United States (U.S. Department of Homeland Security 2007). Most industrialized countries experiencing labor shortages are currently using migration as a source of additional workers to meet the growing demand. There has been a steady increase in the immigrant population in most OECD countries in the past decade. In 2004 foreign-born/foreign labor accounted for more than $11 \%$ of the total labor force in most of these countries (Table 5). Industrialized countries such as South Korea and Malaysia are also facing the same problem of workforce shortages. This is currently managed by hiring foreign workers on the basis of temporary visas. For example, foreign labor in South Korea accounted for 1\% of its total labor force in 2004. In 2007 Malaysia had 1.9 million (mostly low and semi-skilled) foreign workers which accounted for about $17 \%$ of its national labor force (Table 6). It is feared that China, with its 'one-child per family' population policy in force, may soon face a major labor shortage problem if its government continues with its policy of to maintaining high speed industrialization and economic growth.

Table 5: Foreign-born Labor Force in Selected OECD Countries

\begin{tabular}{|l|l}
\hline Country & Foreign-born Labor Force \\
\hline
\end{tabular}




\begin{tabular}{|l|c|c|c|}
\hline \multirow{2}{*}{} & \multicolumn{2}{|c|}{ Thousands } & $\begin{array}{c}\text { \% of Total Labor } \\
\text { Force }\end{array}$ \\
\cline { 2 - 4 } & $\mathbf{1 9 9 9}$ & $\mathbf{2 0 0 4}$ & $\mathbf{2 0 0 4}$ \\
\hline Australia & 2242 & 2474 & 24.9 \\
\hline Austria & 440 & 585 & 15.3 \\
\hline Belgium & 450 & 512 & 11.5 \\
\hline Canada & -- & 2567 & 17.5 \\
\hline France & 3013 & 2987 & 11.3 \\
\hline Germany & 4241 & 4800 & 12.2 \\
\hline Italy & 213 & 1350 & 5.6 \\
\hline Japan & 126 & 192 & 0.3 \\
\hline The Netherlands & 684 & 929 & 11.1 \\
\hline Spain & 645 & 2241 & 11.2 \\
\hline Sweden & 428 & 606 & 13.3 \\
\hline $\begin{array}{l}\text { United } \\
\text { Kingdom }\end{array}$ & 2293 & 2759 & 9.6 \\
\hline United States & 17058 & 21995 & 15.1 \\
\hline
\end{tabular}

Source: Constructed from Table 1.8, International Migration Outlook: Annual Report 2006, OECD

Table 6: Population and Labor Force in Malaysia, 2007

\begin{tabular}{|l|l|}
\hline Population (million) & 26.6 \\
\hline Working-age Group (million) & 16.8 \\
\hline Labor Force (million) & 11.0 \\
\hline Number of Employed Persons (million) & 10.6 \\
\hline Population Growth Rate (\%) & 1.74 \\
\hline Projected Population 2025 (million) & 34.5 \\
\hline Projected Population 2050 (million) & 40.5 \\
\hline Foreign Workers (million) & 1.9 \\
\hline
\end{tabular}

Source: Labor Force Survey Report 2007, Department of Statistics, Malaysia

However, in the world context migration is a zero-sum game. An increase in the number of migrant populations in receiving countries is actually equal to a fall in the number of people in the sending countries. Developing countries are the sources of most immigrants to industrialized nations. There is a rising interest in the international political economy of migration of labor from the developing to the developed countries. To these industrialized and capital-abundant host countries, immigrants are welcome additions to their labor supply. The additional workers (immigrants) are essential for increasing the efficiency and productivity of their stock of human capital, land, and natural resources. To the source or sending countries migration means reductions to their human capital stock. This, however, has the potential to negatively impact their economic development, now and in the future. Therefore, immigration cannot be a sustainable solution for the world economy. It requires the world population to grow in order to meet the growing demands of the labor force for economic sustainability and prosperity. 


\section{Sustainable Solutions: Technological Innovations}

As noted earlier, a sustainable solution of the problem demands the world population to grow to meet the need for economic sustainability and economic growth. To support the growing population this can only occur if the earth's carrying capacity also increases. This requires rate of advances in technology to increase in terms of production capacity and efficiency without destroying the natural environment. Earlier we noted that the planet's capacity to support any sustainable size of population depends primarily on the state of a given society's expected lifestyle (including distribution of population and resources) and level of technological sophistication (Desvaux 2007). The higher the affluence (i.e. more consumption and use of resources) means that the earth can only support a smaller population; the more equitable is the distribution of population and resources then the earth can support more people. As well, the more sophisticated is the technology (greater capacity to unlock more resources from the environment) then a larger population can be supported. Affluence is negatively related while equitable distribution of population and technological capacity is positively related to the earth's population carrying capacity. Therefore, the solution to the problem of declining work-age population is evident through a policy of planned population growth supported by innovations in both social and industrial engineering and technology.

\section{a. Social Engineering and Technology}

Early human societies lived with few material possessions. However, over time they invented and developed technologies and systems to unlock from nature more and more resources necessary for supporting affluent life. In the process they seem to have abandoned the principle of 'simple living and high thinking'. Today, they have turned into 'consumer societies' with a strong love for more and more material things, as if they 'live only to eat'. However, this is no answer to the ethical and environmental demands that future social engineering and technological advances should be geared to developing a practicable lifestyle based on a 'slim-green' consumption choice founded on the principle of 'simple living and high thinking'. Living more simply will result in saving and conserving natural resources, waste minimization, etc. It will enhance the earth's capacity to carry a larger sustainable population. In addition, it may also focus on the planned redistribution of population from the resource-poor crowded countries to the resource-rich yet sparsely populated countries. This will help to temporarily reduce labor shortage problems in some countries and labor unemployment problems in others.

\section{b. Industrial Engineering and Technology}

In the future, industrial engineering and technology development will be able to focus on the following areas: (a) Labor-saving technology; (b) Resource-saving technology; and (c) Resources-creating technology. These are explained in more detail below:

a. Labor-Saving Technology: Labor-saving technology refers to the minimization of human labor. Since the work-age population is projected to decline and the environment is the great reservoir of untapped resources, these two aspects will be prioritized for future technological development (Lovins et al. 2007). These are possibly the most easily addressed areas where problems can be solved. For resolving the issue of declining work-age population, development of more labor-saving technologies is deemed necessary. Since most modern technologies by nature are 
labor-saving and resource-consuming in any case, such technology will have to sophisticated enough to avoid the use of more natural resources.

b. Resource-Saving Technology: Resource-saving technology, in terms of method, process and product, will enable the production of outputs with less resources. For instance, the energy-saving light bulb consumes less energy to produce the same amount of light. The system of quicker growing livestock and poultry, genetically modified organisms (GMOs) and hybrid foods, etc., are the products of such technologies. In future, increasingly more and more such technologies are expected to be developed.

c. Resource-Increasing Technology: Resource-increasing technology will be the most challenging thing to create in future societies. Such technologies will be able to unlock new resources from the environment, for example finding or producing new outputs from the sea, desert, air, sunlight, etc. Growing seaweed as a food item, solar energy for photovoltaic cells, wind mills, etc., can be developed through this kind of technology which still in its infancy and mostly untapped. Future technological development should mostly focus on the cultivation of the desert, sea, and solar environment for creating more new renewable resources so that the earth can support increasing human populations. Resource-increasing technology includes the utilization of unused and rival resources like waste which can be recycled for production purposes. In fact, the level of successes in the resource-creating technology will largely determine if the earth can support the projected increases in the world's population.

Successes in the labor-saving technology may lead to the declining work-age population in the context of the present population stabilization policy being sustained. However, successes in the resource-saving and resource-creating technologies is a more longterm solution to the problem. These make it possible to purse a more liberal population growth policy to overcome the danger posed by a declining work-age population. For a lasting and sustainable solution, the resource-saving and resource-creating technologies will benefit future generations. Nonetheless technological developments and their spread have their limitations. We need to remember that technology production does not follow a function of constant return to scale; doubling the number of researchers and other facilities will not necessarily double the output. Advanced technology production could decline for two reasons: firstly, many researchers work to produce the same thing, and this is simply a duplication of effort; and secondly, the maintaining the same rate of technological growth will put pressure on R\&D experts to keep making new discoveries or new technologies which is very difficult to maintain (Weil 2009, p. 257). We may devote more time and resources to R\&D but there is no guarantee of quick success. A technology's acceptance in and spread throughout an economy as a whole may take several decades to occur. For example, in 1964 Meredith Thring predicted that in 10 to 20 years' time robots would be widely used for all routine operations around the home (Weil 2009, p. 264). Yet this is still not the case in the year 2019.

However, it may not be quite ridiculous and meaningless to imagine that the technological developments of the future world will be such that many of the requirements of the present-day life style will become irrelevant and redundant. Most private goods will become public goods and people will not have to travel away from home as much for working in an office, shopping, making social visits, etc. Minimum attendance time at the 
workplace, school classes, hospitals, recreation places, shopping places, etc., may become the way of the future, now that so much of life is conducted online. People's homes will become their offices, workplaces, and/or classrooms. It is envisaged that society will be more ethical and health conscious and will gradually abandon consumerism. In fact, there are already many indications that this is now happening. The spirit of this new lifestyle may be observed in the paradoxically 'traditional' way of life espoused by the Amish community in Pennsylvania, USA. Such a resource-saving lifestyle as the one they live will help the planet to support a larger population.

\section{CONCLUSIONS}

Both economic and environmental sustainability are required for the sustainability of humankind. Continuous decline in fertility and death rates is causing the old-age dependency ratio to rise. For that reason, the coming decades will become very challenging for the workage population who will not have the numbers to support the increasing economically inactive people. Especially during 2050 and beyond an economic crisis is likely to prevail worldwide. The appropriate solution to this worldwide potential problem must be sought through a policy of maintaining the optimal rate of world population growth which is consistent with changing social trends and technological advances. The resulting lifestyle that people want must be in accord with what the planet earth can support. At the same time, the earth's increasing food production capacity to feed its expanding population will depend on improved technologies, biotechnological revolution, wider range of food sources (e.g. from the sea, for example), more land made available for production, and, in particular, more production in the regions where it is needed. However, much will depend on political wisdom, will, and resolutions made by the global community.

Finally, this analysis makes important contributions to the literature on population and economic sustainability theories by introducing and linking the key concepts. It sets out certain implications for and impacts of change in in people's lifestyles if the desired industrial and social engineering and technological developments are in fact successful. Life is envisioned as an ethical and environmentally friendly one where resources are saved and consumerism is rejected. What is discussed in this paper is a new addition to the literature and will guide the direction for future theoretical constructs in this field of research.

\section{REFERENCES}

Alam, M.M., Molla, R.I., Rahman, K.M. and Murad, M.W. (2009). A paradox of the world population stabilization policy, The Journal of Developing Areas, 43(1), 131-140. (online) https://www.jstor.org/stable/40376287 (Accessed on $28 \mathrm{Feb}, 2019$ )

Brundtland, G.H. (1987). Our common future. New York: Oxford University Press.

Buringh, P. (1982). Potentials of world soils for agricultural production. In 12th International Congress of Soil Science, New Delhi, 33-41.

Buringh, P., van Heemst, H.D.J. \& Staring, G.J. (1975). Computation of the absolute maximum food production of the world, Department of Tropical Soil Science, Agricultural University, Wageningen.

Cohen, J.E. (1992). How many people can earth hold? Discover, 13(11), 114-119. (online) http://discovermagazine.com/1992/nov/howmanypeoplecan152 (Accessed on $28 \mathrm{Feb}$, 2019)

Cohen, J.E. (1995a). How many people can this earth support? Sciences, 35(6), 18-23.

Cohen, J.E. (1995b). How many people can this earth support? New York: W.W. Norton. 
Department of Statistics (Malaysia) (2007). Labor force survey report - third quarter 2007. Putrajaya: Department of Statistics, Government of Malaysia.

Desvaux, M. (2007). The sustainability of human populations: how many people can live on earth? Significance, 4(3), 102-107. http://www.optimumpopulation.org/HowManyPeople.pdf (Accessed on 23 April, 2011)

Dimick, D. (2014). As World's Population Booms, Will Its Resources Be Enough for Us?, National Geographic.

(online) https://news.nationalgeographic.com/news/2014/09/140920-population-11billiondemographics-anthropocene/ (Accessed on $28 \mathrm{Feb}, 2019$ )

Dudal, R. (1982). Land degradation in a world perspective. Journal of Soil and Water Conservation, 37, 245-249.

Ehrlich, P. R. (1968). The population bomb. New York: Ballantine Books.

Ehrlich, P.R. \& Ehrlich, A.H. (1990). The population explosion. London: Hutchinson.

Elferink, M. \& Schierhorn, F. (2017). Global Demand for Food Is Rising. Can We Meet It?. Harvard Business Review, April 07. (online) https://hbr.org/2016/04/global-demandfor-food-is-rising-can-we-meet-it (Accessed on $28 \mathrm{Feb}, 2019$ )

Emmott, S. (2013). Humans: the real threat to life on Earth. (online) https://www.theguardian.com/environment/2013/jun/30/stephen-emmott-ten-billion (Accessed on $28 \mathrm{Feb}, 2019$ )

Emmott, S. (2015). Though climate change is a crisis, the population threat is even worse. (online) https://www.theguardian.com/commentisfree/2015/dec/04/climate-changepopulation-crisis-paris-summit (Accessed on $28 \mathrm{Feb}, 2019$ )

FAO. (2003). World Agriculture: Towards 2015/2030, Rome. (online) http://www.fao.org/3/a-y4252e.pdf (Accessed on 28 Feb, 2019)

Fremlin, T. (1964). How many people can the world support? New Scientist, October 29. (online) http://books.google.com/books?id=hYVZ35VQmE8C\&lpg=PA285\&ots=ZANGtQwTV\&dq=How\%20many\%20people\%20can\%20the\%20world\%20support\% 3F\%20New\%20Scientist\&pg=PP1\#v=onepage\&q=How\%20many\%20people\%20can $\% 20$ the \%20world\%20support?\%20New\%20Scientist\&f=false (Accessed on 23 April, 2011)

Godfray J., Beddington R., Crute R., \& Muir F. (2010). Food Security: The challenge of Feeding 9 Billion People. Science, 327(5967), 812-818.

Greenland, D.J., Gregory, P.J. \& Nye, P.H. (1997). Introduction and conclusions. In Greenland, D.J., Gregory, P.J. \& Nye P.H. (Eds). Land resources: on the edge of the Malthusian precipice? 861-867. London: The Royal Society.

Hall, C., Dawson, T.P., Macdiarmid, J.I., Matthews R.B., \& Smith, P. (2017). The impact of population growth and climate change on food security in Africa: looking ahead to 2050, International Journal of Agricultural Sustainability, 15(2), 124-135.

Hasell, J. (2018). Does population growth lead to hunger and famine? Our World in Data. (online) https://ourworldindata.org/population-growth-and-famines (Accessed on 28 Feb, 2019)

Hincks, J. (2018). The World Is Headed for a Food Security Crisis. Here's How We Can Avert It. (online) http://time.com/5216532/global-food-security-richard-deverell/ (Accessed on $28 \mathrm{Feb}, 2019$ )

Hunter, A. (2016). The effect of population growth on efficiency in food production. (online) https://www.potatopro.com/news/2016/effect-population-growth-efficiency-foodproduction (Accessed on $28 \mathrm{Feb}, 2019$ ) 
Japan Institute for Labor Policy and Training (JILPT) (2007a). Japanese working life profile 2006/2007 - labor Statistics. Tokyo: Japan Institute for Labor Policy and Training. (online) https://www.jil.go.jp/english/jwl/2006-2007.pdf (Accessed on 28 Feb, 2019)

Japan Institute for Labor Policy and Training (JILPT) (2007b). Achieving a society where people will be able to actualize capacity, will have work security, and will have safe life - a solid approach to declining population (In Japanese). Tokyo: Japan Institute for Labor Policy and Training.

Latham, J.R. (2000). There's enough food for everyone, but the poor can't afford to buy it, Nature, 404, 222. (online) https://www.nature.com/articles/35005264 (Accessed on 28 Feb, 2019)

Lovins, A., Lovins, L.H., \& P. Hawken (2007). A road map for natural capitalism. Harvard Business Review, July-August. (online) https://hbr.org/2007/07/a-road-map-fornatural-capitalism (Accessed on $28 \mathrm{Feb}, 2019)$

Moody, O. (2017). Overpopulation is the biggest threat to mankind, Nobel laureates say, The Times, Aug 31. (online) https://www.thetimes.co.uk/article/overpopulation-is-thebiggest-threat-to-mankind-nobel-laureates-say-zxdnv2bcv (Accessed on 28 Feb, 2019)

Myrskyla, M., Kohler, H.P, \& Billari, F.C. (2009). Advances in development reverse fertility declines. Nature, 460, 741-743.

OECD Factbook (2009). Economic, environmental and social statistics. Paris: OECD Publishing. (online) http://www.oecdilibrary.org/docserver/download/fulltext/3009011ec005.pdf?expires $=1303542514 \&$ id =id\&accname $=$ freeContent $\&$ checksum $=50 F C 1 \mathrm{~A} 08328 \mathrm{DF} 0 \mathrm{~F} 3 \mathrm{DB} 5 \mathrm{A0F} 6 \mathrm{~B} 9 \mathrm{~B} 81 \mathrm{~A} 1 \mathrm{C} 4$ (Accessed on 23 April, 2011)

Organization for Economic Co-operation and Development (OECD) (2006). International migration outlook: annual report 2006. Paris: Organization for Economic Cooperation and Development. (online) http://www.oecd.org/els/mig/internationalmigrationoutlook2006.htm (Accessed on 28 Feb, 2019)

Paul R. \& John P. (2011). Impact of Population Growth. Science, New Series, 171 (3977), $1212-1217$.

Penck, A. (1928). Das Haupt problem der physischen Anthropogeographie, In First International Congress of Soil Science, Washington DC, 98-116.

Penning de Vries, F.W.T., Rabbing, R. \& Groot, J.J.R. (1997). Potential and attainable food production and food security in different regions. In: Greenland, D.J., Gregory, P.J. \& Nye, P.H. (Eds). Land resources: on the edge of the Malthusian precipice? 917-928. London: The Royal Society.

Pimentel, D., Harman, R., Pacenza, M., Pecarsky, J. \& Pimentel, M. (1994). Natural resources and an optimum human population. Population and Environment, 15(5), 347-369.

(online)

http://www.mnforsustain.org/pimentel_d_natural_resources_and_optimum_populatio n.htm (Accessed on 28 Feb, 2019)

Pinstrup-Andersen, P. (1998). Food security and sustainable use of natural resources: a 2020 vision, Ecological Economics, 26, 1-10.

Population Action International (2011). Why Population Matters to Food Security. (online) https://pai.org/wp-content/uploads/2012/02/PAI-1293-FOOD_compressed.pdf (Accessed on $28 \mathrm{Feb}, 2019)$

Population Connection (2019). Population Growth and Food Insecurity. (online) https://www.populationconnection.org/article/population-growth-food-insecurity/ (Accessed on $28 \mathrm{Feb}, 2019$ ) 
Population Fact (2017). The end of high fertility is near. Population Division, Department of economics and Social Affairs, United Nations. (online) https://population.un.org/wpp/Publications/Files/PopFacts_2017-3 The-end-of-highfertility.pdf (Accessed on 28 Feb, 2019)

Prasad, R. (2013). Population growth, food shortages and ways to alleviate hunger. Current Science, 105(1), 32-36.

Ross, C. (1999). Can we feed the world in 2020? New Zealand Soil News, 47, 137-141.

Sen, A. (1994). Population: Delusion and Reality, New York Review of Books. (online) https://www.nybooks.com/articles/1994/09/22/population-delusion-andreality/(Accessed on $28 \mathrm{Feb}, 2019)$

Singh, S. (2009). Global food crisis: magnitude, causes and policy measures, International Journal of Social Economics, 36(1/2), 23-36.

Spidla, V. (2005). Opening speech at the international population conference. France: Tours.

Team, F. (2009). Global food production will have to increase $70 \%$ for additional 2.3 billion people by 2050, Finfacts Ireland. (online) http://www.finfacts.ie/irishfinancenews/article_1017966.shtml (Accessed on 28 Feb, 2019)

Todaro, M.P. \& Smith, S.C. (2009). Economic development. New York: Addison Wesley (10 ${ }^{\text {th }}$ Edition).

U.S. Census Bureau (2000). International database. Washington, DC: Population Division.

U.S. Census Bureau (2004). Global population profile: 2002. Washington, DC: Population Division. (online) http://www.census.gov/prod/2004pubs/wp-02.pdf (Accessed on 28 Feb, 2019)

U.S. Department of Homeland Security. (2007). Yearbook of immigration statistics: 2007. (online) https://www.dhs.gov/immigration-statistics/yearbook/2007 (Accessed on 28 Feb, 2019)

Weil, D.N. (2009). Economic growth. Boston: Pearson Addison Wesley.

World Bank (2004). Energy production and use; energy efficiency, dependency and emissions - world development indicators 2004 (Compact Disk version). Washington DC: World Bank.

World Economic Outlook (2004). How will demographic change affect the global economy? Washington DC: International Monetary Fund. (online) https://www.imf.org/ /media/Websites/IMF/imported-flagshipissues/external/pubs/ft/weo/2004/02/pdf/_chapter3pdf.ashx (Accessed on $28 \mathrm{Feb}$, 2019)

World Health Organization (2002). World health report 2002. Geneva: World Health Organization. (online) http://www.who.int/entity/whr/2002/en/whr02_en.pdf (Accessed on 28 Feb, 2019)

Worldometers (2019). World Population. (online) http://www.worldometers.info/worldpopulation/\#table-forecast (Accessed on $28 \mathrm{Feb}, 2019$ )

Worldwatch Institute (1998). A matter of scale - Population and Food. World Watch, 11(3), 1-39. (online) http://www.worldwatch.org/node/768 (Accessed on 28 Feb, 2019)

\section{Author Biographies:}

Dr. Md. Mahmudul Alam is a Senior Lecturer of Finance at Universiti Utara Malaysia, and a Research Fellow at Frankfurt School of Finance \& Management, University Technology MARA, and International Islamic University Chittagong. He obtained his PhD and Master's degrees in Environment and Development (Finance \& Economics) from National University 
of Malaysia. He has many publications, including 100 plus articles in refereed journals and five books/monographs. He has presented more than 70 articles at international conferences. $\mathrm{He}$ is recognized by BDRC as one of the "Top Bangladesh Development Researchers of the Millennium". His research areas include sustainable finance, sustainable development, ecological economics, financial economics and Islamic economics.

Dr Md. Wahid Murad is currently a lecturer in economics and business at the University of South Australia. Previously, he worked at the University of Adelaide, South Australia and University of Malaysia Terengganu, Multimedia University in Malaysia in various positions, including lecturer, senior lecturer, head of economics discipline and an Associate Dean. Dr Murad has nearly 16 years of teaching experience and has been a researcher for over 21 years in Australia, and Malaysia. He has taught at undergraduate and postgraduate levels and supervised HDR students to completion. He has published a book, chapters in several books, and research articles in nearly 50 scholarly international journals in the areas of economic globalization, socioeconomics, tourism economics, environment, and development economics.

Professor Dr. Rafiqul Islam Molla is now an Honorary Professor in Economics at International Islamic University Chittagong, Bangladesh. He has a 57-year long successful teaching career serving various universities including: Bangladesh, Kenya, Nigeria, Uganda, and Malaysia as an educator, Head of Department, Dean of Faculty, University Academic Adviser, etc. He obtained the B.Com (Hons) and M.Com. degrees from Dhaka University, Bangladesh, and received a talent scholarship. He received his $\mathrm{PhD}$ in Agricultural Economics from Texas A \& M University, USA, in January 1970 and had the pleasure of receiving the USAID Scholarship. Again, with the USAID Scholarship he attended a 3-month intensive summer course with the International Marketing Institute, Harvard University Campus, USA. He founded the Bangladesh Association for Total Social Advancement.

Dr. Khondaker Mizanur Rahman is a professor working at Nanzan University, Japan. He is an Honors graduate in commerce from Dhaka University, Bangladesh, and received his $\mathrm{PhD}$ in Business Management from Chuo University, Japan, in March 1990. He has more than 35 years of teaching and research experience in Bangladesh, and Japan. During 1990-1994 he was a full-time researcher at United Nations Centre for Regional Development (UNCRD), Nagoya, Japan. He published 8 books and as many as 80 research papers in academic journals. He was a Visiting Scholar at Fairbank Center of East Asian Studies, Harvard University, USA for one year during 1998-1999. Then between 2009-2011 he was a Visiting Professor at the School of Commerce and Law, Central Queensland University, Australia.

Ms. Taslima Rahman Khondaker is currently a lecturer at the Foreign Language Education Center, Nanzan University, Nagoya, Japan. She obtained her B.Sc. (Hons) from Usmanu Danfodiyo University Sokoto (UDUS), Nigeria in 1989 and M.Sc. from Nagoya University, Japan in 1995. She has over 11 years of teaching experience at several universities in Japan. From January to December 1990, she worked as a full-time researcher at the Department of Zoology, Bangladesh Agricultural University, Mymensingh. Furthermore, she has published a number of research papers in various academic journals and conference proceedings. 